\title{
Introduction of sorghum [Sorghum bicolor (L.) Moench] green manure in rotations of head salads and baby leaf crops under greenhouse
}

\author{
Luigi Morra, Domenico Cerrato, Maurizio Bilotto, Salvatore Baiano \\ Research Centre for Cereal and Industrial Crops, Council for Agricultural Research and Economics, \\ Laboratory of Caserta, Italy
}

\begin{abstract}
This paper deals with the introduction in tunnel-greenhouses of sweet sorghum cultivated in short, summer cycle as green manure with the aim to amend soils with biomass grown on farm. This practice has been spreading in tunnels of Sele river Valley (Salerno, Italy) where baby leaf crops are cultivated in numerous cycles (up to 5-7) per year. Three sorghum varieties for forage or biomass (Goliath, BMR 201, and BMR 333) were cultivated in two farms at Eboli and San Marzano sul Sarno with the aim of studying their responses in term of fresh and dry aboveground biomass yielded, carbon (C) and nitrogen (N) content of the biomass incorporated in soil, and $\mathrm{C}$ balance in amended soils after one year of ordinary cash crop sequences. No differences, with regard to all the parameters measured, were pointed out among the tested varieties in each site. The sorghum cycle lasted 45 days at Eboli, yielding on average 98 and $13 \mathrm{t} \mathrm{ha}^{-1}$ of fresh and dry biomass, respectively; soil biomass incorporation supplied on average $5.8 \mathrm{t} \mathrm{ha}^{-1}$ of organic $\mathrm{C}$ and $273 \mathrm{~kg} \mathrm{ha}^{-1}$ of total $\mathrm{N}$. In the farm of San Marzano, sorghum cycle lasted 68 days, yielding 116 and $18 \mathrm{tha}^{-1}$ of fresh and dry biomass, respectively; soil biomass incorporation supplied on average $8 \mathrm{tha}^{-1}$ of organic $\mathrm{C}$ and $372 \mathrm{~kg}$ $\mathrm{ha}^{-1}$ of total N. After one year, the plots amended with sorghum biomass showed a soil organic carbon (SOC) concentration not different from the starting point, while SOC decreased in fallow
\end{abstract}

Correspondence: Luigi Morra, Research Centre for Cereal and Industrial Crops, Council for Agricultural Research and Economics, Laboratory of Caserta, Italy.

E-mail: luigi.morra@crea.gov.it

Key words: Sorghum cover crop; Aboveground biomass; N recovery; Soil C balance.

Conference presentation: SIA XLIV Congress, Bologna, 2015.

Received for publication: 28 January 2016.

Revision received: 26 September 2016.

Accepted for publication: 3 October 2016.

(C) Copyright L. Morra et al., 2017

Licensee PAGEPress, Italy

Italian Journal of Agronomy 2017; 12:753

doi:10.4081/ija.2016.753

This article is distributed under the terms of the Creative Commons Attribution Noncommercial License (by-nc 4.0) which permits any noncommercial use, distribution, and reproduction in any medium, provided the original author(s) and source are credited. plots. At Eboli, initial SOC content was $12.3 \mathrm{~g} \mathrm{~kg}^{-1}$, but one year later it resulted 12.3, 12.8, 12.2 and $11.3 \mathrm{~g} \mathrm{~kg}^{-1}$ in BMR 201, BMR 333, Goliath and control plots, respectively. At San Marzano, initial SOC content was $11.4 \mathrm{~g} \mathrm{~kg}^{-1}$, but one year later it resulted 11 , 12, 10.7 and $10.5 \mathrm{~g} \mathrm{~kg}^{-1}$ in BMR 201, BMR 333, Goliath and control plots, respectively. The annual $\mathrm{C}$ balance put in evidence that the green manure with sorghum biomass caused SOC losses higher than those detected in fallow plots. This let us suppose a prime effect in boosting the soil microbial $\mathrm{C}$ mineralisation. Only cv BMR 333 in the Eboli trial pointed out a positive SOC change of $1.8 \mathrm{t} \mathrm{ha}^{-1}$. Further studies are requested to better understand the real efficacy of sorghum cover crop in soil amendment under tunnels devoted to intensive vegetable crop sequence.

\section{Introduction}

The intensive soil exploitation for head salads and fresh-cut leafy vegetables cultivation, used in the preparation of the readyto-eat fresh vegetables, has impaired the chemical, physical and biological balance of soils in Sele river valley during the last 20 years. At least 4500 ha under plastic tunnels and 3000 ha in open fields (data estimated lacking of official statistics) in an alluvial plain extended over 50,000 ha have been involved in a process whose final exit on soil fertility and productivity is unpredictable at the moment. Compared to the conventional cropping systems in greenhouses, based on 2-3 crop cycles per year with tomato, pepper, eggplant, muskmelon, lettuce, etc. as vegetables, the production of leafy vegetables increased the crop intensification in terms of number of crop cycles (up to 5-7 per year) and number of soil tilling per year (Penati et al., 2009). In this regard, it should be clarified that the seedbed preparation of any crop requires a sequence of chiseling, spading machine, 2-3 rototilling. The lack of significant and repeated soil organic amendment has triggered a decline in soil organic carbon (SOC) under these intensive farming systems (Morra et al., 2015). Bonanomi et al. (2011) pointed out that long-lasting soil cultivation under plastic cover in the Sele river basin has negatively affected SOC content, microbial biomass, enzymatic activities, functional and species diversity, soil salinity. SOC is a critical functional component of soil ecosystem because it provides the substrate to microbes, improves soil structure and water holding capacity. The average SOC content detected in most of the local farms devoted to these intensive crop systems is around $1 \%$, with minimum value of $0.5 \%$ and maximum of $1.3 \%$. These values are strictly consistent with the map of SOC content of European soils (Jones et al., 2004; Zdruli et al., 2004) showing that the Mediterranean regions of Europe exhibit distinctively smaller values of SOC, with substantial areas showing very low SOC $(\leq 1 \%)$ or low SOC $(\leq 2 \%)$ (EIP-AGRI Focus Group, 2015). The agronomic and environmental criticalities 
described above are persuading farmers to look for some solutions with regard to the appropriate organic biomasses to be used as soil conditioners. At present, the use of organic amendments such as manure or biowaste compost arises many suspicions in a large part of European food retailers about the risk of plant food contamination owing to foodborne pathogens. Therefore, buyers have imposed farmers some guidelines to forbid the use of manure or biowaste compost. The recent introduction of sorghum as cover crop under tunnels in Sele river basin represents an attempt to escape from these constraints by producing organic biomass for soil fertilisation directly in the farms (Colucci, 2012). Farmers cultivate sorghum in 40-50 day cycles, in summer. Sorghum cover cropping has diffused mostly in the organic farms (400 ha in Sele river valley), where the interruption of the annual cash crop sequence with a botanically different grass is compulsory. Major constraint to sorghum cultivation in integrated production farms is not the cost of irrigation because every farm uses water from its own wells, but the unproductiveness of cover crop. The lack of a thoroughly cost-benefit evaluation enables an informed choice. Certainly, in baby-leaf crop systems producing high gross income it should be possible to sustain costs for a two-month cover crop. As an example, a cropping system that produces only rocket and basil with a total of 6 cuts per year allows a gross income of 50,000 $€ \mathrm{ha}^{-1}$ at least (Terramore producer organisation, personal communication).

Substantial research has been conducted on winter annual cover crops, but very little has been conducted on summer cover crops for green manuring. Creamer and Baldwin (2000) carried out a study to evaluate several potential summer cover crops and their mixtures to be introduced in a vegetable crop rotation. They tested some legumes and broadleaves species (e.g.: Vigna unguiculata, Sesbania exaltata, Glycine max, Fagopyrum esculentum, Sesamum indicum) and some grass (e.g.: Pennisetum glaucum, Setaria italica, Sorghum sudanense, S. bicolor $\times S$. sudanense). The authors found that sorghum-sudangrass in a two-month cycle in open field at a seeding rate of $39 \mathrm{~kg} \mathrm{ha}^{-1}$ produced the highest amount of dry aboveground biomass $\left(8.8 \mathrm{tha}^{-1}\right)$, with $\mathrm{C}: \mathrm{N}$ ratio 53 and an uptake of $88 \mathrm{~kg} \mathrm{~N} \mathrm{ha}^{-1}$. Sorghum in general can be classified into two types: forage (mainly for forage, fibre, biomass or animal feed) and grain (mainly for human consumption). Sorghum [Sorghum bicolor (L.) Moench] is a warm-season $\left(\mathrm{C}_{4}\right.$ photosynthetic pathway), short-day annual grass. It grows best under high temperature and sunny conditions. It is more drought-tolerant but it requires irrigation during summer. Sorghum is considered the most productive annual crop to yield biomass. In Southern Italy, water consumption of the crop in optimal conditions reaches up to 7000$8000 \mathrm{~m}^{3} \mathrm{ha}^{-1}$ (Cosentino et al., 2011). However, numerous experimental trials demonstrated that a reduction of the irrigation volumes increases water use efficiency. Cosentino (1996), in Sicily, ascertained that to an increasing water volume of $1000 \mathrm{~m}^{3} \mathrm{ha}^{-1}$ corresponded a yield increase of $5 \mathrm{tha}^{-1}$ as dry matter (DM) up to a volume of $4000 \mathrm{~m}^{3}$, beyond which the increase becomes less evident. Garofalo et al. (2011) studied the productivity of sorghum in terms of biomass and its capacity to convert efficiently water and solar radiation in a Mediterranean environment (Foggia). In a cycle from May to August, a crop seeded at 25 seeds $\mathrm{m}^{-2}$, yielded a biennial average of $34 \mathrm{t} \mathrm{ha}^{-1}$ of DM in well-watered conditions (on average $7700 \mathrm{~m}^{3} \mathrm{ha}^{-1}$ whose 4200 by irrigation). Sorghum showed high values of water and solar radiation use efficiency $\left(5.87 \mathrm{~g} \mathrm{~L}^{-1}\right.$ and $2.84 \mathrm{~g} \mathrm{MJ}^{-1}$, respectively). In a two-year experiment, Cosentino et al. (2002) estimated that reducing water supply to $50 \%$ of the crop evapotranspiration (ETc) (on average $3500 \mathrm{~m}^{3}$ ) the sorghum yield decreased of $31 \%$ (on average $18 \mathrm{tha}^{-1} \mathrm{DM}$ ), while the irrigation water use efficiency (IWUE) increased from 4.4 (optimal supply) to $5.3 \mathrm{~g} \mathrm{~L}^{-1}$. Campi et al. (2014) showed that the DM (16.8 $\left.\mathrm{t} \mathrm{ha}^{-1}\right)$ of biomass sorghum irrigated with $2012 \mathrm{~m}^{3}$ $\mathrm{ha}^{-1}$, a $50 \%$ restoring of ET, decreased of $17 \%$ in comparison to fully water restored treatment.

In this paper, we present the results of two sorghum green manure trials carried out in intensive cropping systems under tunnel-greenhouses: Eboli (in Sele river basin) and San Marzano sul Sarno (in Sarno river basin). Our objective was to know the amount of fresh and dry sorghum biomass achievable in a short cycle with the limited irrigation regimes usually adopted by farmers. Besides, we measured the plant tissue content in $\mathrm{OC}$ and total $\mathrm{N}$ to quantify on the one hand the amount of OC added to soils and the $\mathrm{C}$ balance after one year, and the soil $\mathrm{N}$ recovered on the other.

\section{Materials and methods}

\section{Treatments and experimental design}

From June to August 2013, we compared a biomass sorghum variety (Goliath) and two forage varieties which possess the brown midrib (BMR) trait determining brown vascular tissue as a result of their reduced lignin content (BMR 333 and BMR $201 \mathrm{MH}$ ). Fallow plots were the not-treated control. Therefore, a randomised complete block with three replications was adopted in each trial. The experimental plot measured $125 \mathrm{~m}^{2}$, so the whole area involved in each trial was about $1500 \mathrm{~m}^{2}$.

\section{Experimental sites}

The sorghum green manure trials were realised under multichapel tunnels in two locations of the province of Salerno: Eboli (in Sele river basin) e San Marzano sul Sarno (in Sarno river basin). In Eboli, the physico-chemical soil characteristics under the tunnel-greenhouses where the trial was carried out are shown in Table 1. Soil texture was clay-sandy, with a low OC content, a medium content of total $\mathrm{N}$, and high contents in exchangeable

Table 1. Physico-chemical characteristics of soils in Eboli and San Marzano sul Sarno before the beginning of sorghum crop as green manure.

\begin{tabular}{lcc} 
Parameter & $\begin{array}{c}\text { Eboli } \\
\text { Sand (\%) }\end{array}$ & $\begin{array}{c}\text { San Marzano } \\
\text { sul Sarno }\end{array}$ \\
Silt (\%) & 42 & 54 \\
\hline Clay (\%) & 8 & 40.5 \\
$\mathrm{pH}(1: 2.5$ in water) & 50 & 5.5 \\
$\mathrm{EC} 25^{\circ} \mathrm{C}\left[\mathrm{dS} \mathrm{m}^{-1}(1: 2\right.$ ratio) & 8.1 & 8.2 \\
Organic $\mathrm{C}\left(\mathrm{g} \mathrm{kg}^{-1}\right)$ & 0.38 & 0.65 \\
\hline $\mathrm{N}$ total $\left(\mathrm{g} \mathrm{kg}^{-1}\right)$ & 12.3 & 11.3 \\
$\mathrm{C} / \mathrm{N}$ & 1.4 & 0.8 \\
\hline Cationic exchange capacity $\left(\mathrm{meq} 100 \mathrm{~g} \mathrm{~g}^{-1}\right)$ & 8.7 & 14.1 \\
$\mathrm{P}_{2} \mathrm{O}_{5}$ availability $\left(\mathrm{mg} \mathrm{kg}^{-1}\right)$ & 29.7 & 28.5 \\
\hline $\mathrm{K}_{2} \mathrm{O}$ exchange $\left(\mathrm{mg} \mathrm{kg}^{-1}\right)$ & 368 & 765 \\
$\mathrm{CaO}$ exchange $\left(\mathrm{mg} \mathrm{kg}^{-1}\right)$ & 3349 & 1067 \\
\hline
\end{tabular}

EC, electrical conductivity; $\mathrm{N}$, nitrogen; $\mathrm{C}$, carbon. All measures follow the Official methods of soil chemical analysis reported in Italian Republic (1999). 
potassium and available phosphorus.

The second farm is in a plain of ancient horticultural tradition where, in the last 40 years, the area under cultivation has been greatly reduced by a strong urbanisation. In San Marzano sul Sarno countryside, 124 hectares were devoted to agriculture in 2010. About 47 ha were covered by tunnels, where head salads are produced. The physico-chemical soil characteristics under the tunnels where the trial was carried out are shown in Table 1. Soil texture was sandy loam, with a low $\mathrm{OC}$ and $\mathrm{N}$ total content, high contents in exchangeable potassium and available phosphorus.

\section{Farming operations}

In Table 2 the volume of irrigation and its distribution along the sorghum cycle are shown. The irrigation water was distributed through a net of sprinklers located at $2.5 \mathrm{~m}$ from the soil surface. The irrigation scheduling, shown in Table 2 , is widely representative of the irrigation management of sorghum cultivated as cover crop under tunnels in Sele river valley. In Table 3 the remaining operations for the sorghum green manure management in both farms are shown. It is worth noticing that the cover crop in Eboli was mowed 24 days before the cover crop in San Marzano sul Sarno due to the bending of the plants before the full bloom. The high density of sowing and the soil $\mathrm{N}$ availability in Eboli favoured excessive shading among plants and the consequent stem elongation. The chopped biomasses were left some days to dry on soil surface before their incorporation. The cash crop sequence in the following 12 months was made up by basil and rocket in Eboli's trial, whereas snap bean, lettuce and pepper were cultivated in San Marzano's trial.

\section{Samplings and laboratory analysis}

On June $3^{\text {rd }}$ and $14^{\text {th }} 2013$ in the farms of San Marzano sul Sarno and Eboli, respectively, samples of soils in the 0-30 cm layer were collected in three replicates to determine SOC concentration. Besides, in each farm three samples of undisturbed soil at depth of $15 \mathrm{~cm}$ were collected in order to determine the bulk density according to the core method (Grossman and Reinsch, 2002). SOC was determined according to the Walkley-Black method described in Colombo and Mondelli (2015). Before the sorghum green manure chopping, the aboveground plant biomass was completely cut in two sampling areas of $0.5 \mathrm{~m}^{2}$ in each experimental plot. The fresh biomass was weighed, then a sub-sample of $1 \mathrm{~kg}$ was dried at $60^{\circ} \mathrm{C}$ for $72 \mathrm{~h}$ in ventilated oven to determine the DM content. The dried samples were ground with the knife mill Pulverisette (Fritsch GmbH, Idar-Oberstein, Germany). In order to determine the concentration of total $\mathrm{C}$ and $\mathrm{N}$ in tissues, two samples per replicate/variety were analysed; a double measure was taken per each sample by a CHNS analyser (Carlo Erba 1500; Carlo Erba, Milan, Italy). On this basis the amount of organic $\mathrm{C}$ and total $\mathrm{N}$ added to soil with sorghum dry biomass was calculated.

On July $29^{\text {th }}$ and on September $12^{\text {th }} 2014$ in the farms of Eboli and San Marzano sul Sarno, respectively, samples of soil in the layer $0-30 \mathrm{~cm}$ were collected in all the plots of the experimental design in order to describe the evolution of SOC concentration after 12 months of the standard cash crop farm management. A SOC stock balance was calculated according to the method of Lazzerini et al. (2014) after one year from the addition to soil of sorghum green manure:

$$
\mathrm{SOC}_{\text {stock }}=\left(\mathrm{BD} \times \mathrm{D} \times 10,000 \mathrm{~m}^{2}\right) \times \mathrm{SOC}_{\text {conc }}
$$

where $\mathrm{SOC}_{\text {stock }}$ is the amount of organic carbon in soil $\left(\mathrm{Mg} \mathrm{ha}^{-1}\right)$, $\mathrm{BD}$ is the soil bulk density $\left(\mathrm{Mg} \mathrm{m}^{-3}\right), \mathrm{D}$ is the thickness of soil layer $(\mathrm{m}), \mathrm{SOC}_{\text {conc }}$ is the concentration of soil organic carbon $\left(\mathrm{g} \mathrm{kg}^{-}\right.$

$\left.{ }^{1}\right)$. In the balance calculation we considered the amount of organic $\mathrm{C}$ introduced with green manure, while we did not consider the crop residues of the two rotations that, presumably, supplied similar organic $\mathrm{C}$ amounts in all the plots treated or not treated with sorghum varieties. Finally, we estimated $\mathrm{C}$ balance on a yearly basis and the conversion efficiency of $\mathrm{C}$ by green manure into SOC (Pagano et al., 2008; Campbell et al., 2002).

\section{Statistical analysis}

The two experiments were separately analysed taking into account the different sowing densities adopted, the different green manure cycle length and the following crop rotation. Data concerning fresh and dry biomass as well as $\mathrm{C}$ and $\mathrm{N}$ contents of biomass

Table 2. Scheduling of the irrigations and total volume of water distributed to sorghum cover crop at Eboli and San Marzano sul Sarno.

$\begin{array}{lc}\begin{array}{l}\text { Scheduling of irrigation } \\ \text { interventions }\end{array} & \text { San Marzano } \\ \text { sul Sarno }\end{array}$

Volumes of water $\left(\mathrm{m}^{3} \mathrm{ha}^{-1}\right)$

\begin{tabular}{lcc} 
At sowing & $240-300$ & 240 \\
\hline $\begin{array}{l}\text { In the successive } 7-10 \text { days, } \\
\text { low water volumes }\left(\max 30 \mathrm{~m}^{3} \mathrm{ha}^{-1} \text { ) frequently }\right.\end{array}$ & 140 \\
$\begin{array}{l}\text { After the emergence of the first true leaf, } \\
6 \text { interventions every } 5 \text { days with } 120 \mathrm{~m}^{3}\end{array}$ & 720 & 720 \\
\hline $\begin{array}{l}\text { After } 38-40 \text { days, end of the irrigation } \\
\text { Total volume }\end{array}$ & 0 & 0 \\
\hline
\end{tabular}

Table 3. Sequence of operations for the management of sorghum cycle in the two farms located at Eboli and San Marzano sul Sarno.

\begin{tabular}{|c|c|c|}
\hline & Eboli & San Marzano sul Sarno \\
\hline Seedbed preparation & Rotavator and cultipacker & Rotavator \\
\hline Sowing date (dd/mm/yy) & $14 / 06 / 2013$ & $20 / 06 / 2013$ \\
\hline Type of sowing & Continuous row with machinery seed drill & Continuous row with hand operated seed drill \\
\hline Rows per plot & 64 rows, $10 \mathrm{~cm}$ among rows & 19 rows, $35 \mathrm{~cm}$ among rows \\
\hline Kilograms of seeds per ha & 70 & 33 \\
\hline Sowing density & 160 seeds $\mathrm{m}^{-2}$ & 70 seeds $\mathrm{m}^{-2}$ \\
\hline Chopping of aboveground biomass & On 07/29/2013, 45 days after sowing & On 08/28/2013, 69 days after sowing \\
\hline Biomass incorporation in soil & Two soil tillage on $08 / 01 / 2013$ and $08 / 08 / 2013$ & Two soil tillage on 09/09/2013 and 09/16/2013 \\
\hline
\end{tabular}


were analysed by one-way analysis of variance (ANOVA). If the experimental factor - sorghum varieties - proved significant for some measured variable, Tukey test $(\mathrm{P}=0.05)$ was performed for means separation. However, group means are always supplied with standard error of mean (SEM) $(n=3)$. Likewise, data about SOC either expressed as concentration or as weight were analysed. Statistical calculations were performed by Software JMP v.12.0.1 (SAS Inc, Cary, NC, USA).

\section{Results}

\section{Site of San Marzano sul Sarno}

Soil bulk density measured under tunnel before the start of green manure was $1.60 \mathrm{~kg} \mathrm{dm}^{-3}$, while the SOC mean content was $11.4 \mathrm{~g} \mathrm{~kg}^{-1}$. In Table 4 is reported the production of the three varieties of sorghum in terms of fresh and dry biomass, $\mathrm{C}$ and $\mathrm{N}$ content of dry biomass and its $\mathrm{C} / \mathrm{N}$ ratio. In 68 day-cycle, sorghum varieties reached a full flowering and they produced a mean fresh biomass of $116.5 \mathrm{t} \mathrm{ha}^{-1}$ without significant differences among the lower value of BMR $201 \mathrm{MH}\left(98.7 \mathrm{t} \mathrm{ha}^{-1}\right)$ and those higher of Goliath and BMR 333 (above $120 \mathrm{t} \mathrm{ha}^{-1}$ ). The corresponding aboveground dry biomass was on average $18.5 \mathrm{t} \mathrm{ha}^{-1}$ without significant differences among the compared varieties. $\mathrm{C}$ concentration in tissues was on average $43 \%$ [standard error (SE) \pm 0.46 ], while total nitrogen was $1.99 \%$ ( $\mathrm{SE} \pm 0.28)$. Therefore, an amount of organic C of 7.6-8.1-8.2 $\mathrm{t} \mathrm{ha}^{-1}$ with BMR 201, BMR 333 and Goliath, respectively, was tilled in the ground. These considerable quantities are comparable to the 7-8.5 $\mathrm{tha}^{-1}$ of $\mathrm{C}$ introduced with 22-27 tha $\mathrm{ha}^{-1} \mathrm{DM}$ of biowaste or olive pomace composts, respectively, in the experiment carried out by Morra et al. (2015) in a baby leaf crop system under greenhouse. $\mathrm{N}$ recovered from soil and fixed in sorghum plants ranged from 330 to $406 \mathrm{~kg} \mathrm{ha}^{-1}$. It is worth to notice the absence of any mineral fertilisation before and during the sorghum growth; the high amount of $\mathrm{N}$ uptaken is an index of the $\mathrm{N}$ soil enrichment determined by the high fertilisations carried out under tunnels in Sarno river basin since 40 years. However, these data are also an index of the sorghum root capacity to recover nutrients from shallow to deep layers of soil. $\mathrm{C} / \mathrm{N}$ ratio of sorghum plants residue ranged from 21 to 25 .

SOC measured after one year from green manure incorporation in soil was $10.5 \mathrm{~g} \mathrm{~kg}^{-1}$ in the control not treated with a decrease of $0.9 \mathrm{~g} \mathrm{~kg}^{-1}$ in comparison with the content at the start of the trial. In plots manured with sorghum varieties, SOC contents resulted of 11, 12 and $10.7 \mathrm{~g} \mathrm{~kg}^{-1}$ for BMR 201, BMR 333 and Goliath, respectively. On the basis of these data, it was estimated the annual carbon balance per each treatment (Table 5). ANOVA did not point out any significant difference among the treatments.

Negative SOC changes were observed in the period T1-T0 (Table 5) either in green manured plots or in control plot except for BMR 333 cropped plot that showed a balance next to zero.

\section{Site of Eboli}

Soil bulk density measured under tunnel before the start of green manure was $1.29 \mathrm{~kg} \mathrm{dm}^{-3}$, while the SOC mean content was $12.3 \mathrm{~g} \mathrm{~kg}^{-1}$. In Table 6 the production of the three varieties of sorghum in terms of fresh and dry biomass, $\mathrm{C}$ and $\mathrm{N}$ content of dry biomass and its $\mathrm{C} / \mathrm{N}$ ratio, is shown. In 45 day-cycle, sorghum varieties produced a mean fresh biomass of $97.8 \mathrm{t} \mathrm{ha}^{-1}$ with significant differences among the lower value of BMR $201 \mathrm{MH}(86.5 \mathrm{t}$ $\mathrm{ha}^{-1}$ ) and those higher of Goliath $\left(105 \mathrm{t} \mathrm{ha}^{-1}\right)$. In Eboli trial, the three varieties yielded a total fresh and dry biomass lower than in the trial at San Marzano. The aboveground dry biomass was on average $13.1 \mathrm{t} \mathrm{ha}^{-1}$ without significant differences among the compared varieties. $\mathrm{C}$ concentration in tissues was on average $43.5 \%$ ( $\mathrm{SE} \pm 0.43)$, while total nitrogen was $1.81 \%(\mathrm{SE} \pm 0.16)$. Organic $\mathrm{C}$ introduced in soil by sorghum biomass ranged from 5 to $6.3 \mathrm{t} \mathrm{ha}^{-1}$, while total $\mathrm{N}$ in sorghum biomass ranged from 213 to $283 \mathrm{~kg} \mathrm{ha}^{-1}$ and $\mathrm{C} / \mathrm{N}$ ratio was on average 25 .

SOC measured after one year from green manure incorporation in soil was $11.3 \mathrm{~g} \mathrm{~kg}^{-1}$ in the control not treated with a decrease of $1.0 \mathrm{~g} \mathrm{~kg}^{-1}$ in comparison with the content at the start of the trial. In plots cropped with sorghum varieties, SOC contents was $12.3,12.8$ and $12.2 \mathrm{~g} \mathrm{~kg}^{-1}$ for BMR 201, BMR 333 and Goliath, respectively.

Table 4. Fresh and dry aboveground biomasses produced by the three sorghum varieties in San Marzano sul Sarno, together with the content of biomasses in organic carbon, total nitrogen and their ratio.

\begin{tabular}{|c|c|c|c|c|c|}
\hline Variety & $\begin{array}{l}\text { Fresh biomass } \\
\qquad\left(\mathrm{t} \mathrm{ha}^{-1}\right)\end{array}$ & $\begin{array}{l}\text { Dry biomass } \\
\text { (t ha- })\end{array}$ & $\begin{array}{c}\text { Organic C } \\
\left(\mathrm{t} \mathrm{ha} \mathrm{a}^{-1} \mathrm{DM}\right)\end{array}$ & $\begin{array}{c}\text { Total N } \\
\left(\mathrm{kg} \mathrm{ha}^{-1} \mathrm{DM}\right)\end{array}$ & $\mathrm{C} / \mathrm{N}$ \\
\hline BMR $201 \mathrm{MH}$ & $98.7( \pm 9.0)$ & $17.8( \pm 2.3)$ & $7.6( \pm 1.0)$ & $330( \pm 69)$ & 25 \\
\hline Goliath & $129.0( \pm 16.2)$ & $19.0( \pm 2.1)$ & $8.2( \pm 0.8)$ & $406( \pm 105)$ & 22 \\
\hline BMR 333 & $121.8( \pm 10.7)$ & $18.9( \pm 1.6)$ & $8.1( \pm 0.8)$ & $380( \pm 26)$ & 21 \\
\hline
\end{tabular}

C, carbon; N, nitrogen; DM, dry matter; BMR, brown midrib. Standard error of means $(\mathrm{n}=3)$ are reported within brackets.

Table 5. Annual balance of soil organic carbon in the 0-30 cm layer after incorporating of the aboveground biomass of three sorghum varieties, San Marzano sul Sarno.

\begin{tabular}{|c|c|c|c|c|c|c|}
\hline San Marzano sul Sarno & $\begin{array}{c}\mathrm{T0} \\
\left(\mathrm{t} \mathrm{ha} \mathrm{h}^{-1}\right)\end{array}$ & $\begin{array}{c}\mathrm{T} 1 \\
(\mathrm{t} \mathrm{ha-1})\end{array}$ & $\begin{array}{c}\text { T1-T0 } \\
(\mathrm{t} \mathrm{ha-1)}\end{array}$ & $\begin{array}{l}\text { Cover crop C input } \\
\left(\mathrm{t} \mathrm{ha}^{-1}\right)\end{array}$ & $\begin{array}{c}\text { C conversion efficiency* } \\
(\%)\end{array}$ & $\begin{array}{l}\text { SOC losses } \\
\left(\mathrm{t} \mathrm{ha} \mathbf{a}^{-1}\right)\end{array}$ \\
\hline Not treated & 54.8 & $51.3( \pm 2.5)$ & $-3.5( \pm 2.5)$ & & & $3.5( \pm 2.1)$ \\
\hline BMR 201 & 54.8 & $52.2( \pm 3.0)$ & $-2.6( \pm 3.0)$ & 7.6 & 0 & $10.3( \pm 2.3)$ \\
\hline Goliath & 54.8 & $51.1( \pm 2.9)$ & $-3.7( \pm 2.9)$ & 8.2 & 0 & $11.9( \pm 2.1)$ \\
\hline BMR 333 & 54.8 & $55.1( \pm 1.1)$ & $0.3( \pm 1.1)$ & 8.1 & $3.7( \pm 10)$ & $7.8( \pm 0.3)$ \\
\hline
\end{tabular}

T0, weight of soil organic carbon before the start of trial; T1, amount of soil organic carbon after about 12 months from biomass incorporation; T1-T0, soil organic carbon change; C, carbon; SOC, soil organic carbon; BMR, brown midrib. * [(T1-T0)/cover crop C input $\times 100$; ${ }^{\circ}$ cover crop C input+(T1-T0). Standard error of means (n=3) are reported within brackets. 
As in the trial of San Marzano sul Sarno, not-treated control pointed out a decrease in SOC, whereas the green manure with different sorghum varieties succeeded only in maintaining the initial level with an increase only for the soil amended with BMR 333 residues. Annual SOC balance confirmed this trend (Table 7). SOC change was clearly negative in control $\left(-4.0 \mathrm{tha}^{-1}\right)$ but where sorghum cover crop was applied the SOC change was next to zero for BMR 201 and Goliath, slightly positive for BMR $333\left(1.8 \mathrm{tha}^{-1}\right)$. As a consequence, only with BMR 333 we recorded a C conversion efficiency of $36 \%$; in the other green manured plots OC introduced with sorghum was completely mineralised.

\section{Discussion}

In a range of 45-69 days, respectively at Eboli and San Marzano sul Sarno, under tunnel-greenhouse, sorghum yielded a dry biomass much greater than the one reported in Creamer and Baldwin (2000) under similar cycle duration, but in open field. Fresh and dry biomass yielded at San Marzano with an irrigation supply of $1080 \mathrm{~m}^{3}$ $\mathrm{ha}^{-1}$ are comparable with the results obtained in open field by Cosentino et al. (2011) with a volume of $3500 \mathrm{~m}^{3} \mathrm{ha}^{-1}$. The IWUE corresponding to this low water supply was on average $17.1 \mathrm{~g} \mathrm{~L}^{-1}$, a level reported by Cosentino et al. (2011) when sorghum was not irrigated. Differently, the yields in Eboli trial with an irrigation supply of $1160 \mathrm{~m}^{3} \mathrm{ha}^{-1}$ and an average IWUE of $11 \mathrm{~g} \mathrm{~L}^{-1}$ were more close to the values found by Cosentino et al. (2011) with a volume of $1920 \mathrm{~m}^{3} \mathrm{ha}^{-1}$ (50\% of ETc). Maddaluno et al. (2011), in 2008-2010 trials carried out in open field at Foggia, recorded an average aboveground dry biomass of $19.8 \mathrm{t} \mathrm{ha}^{-1}$ with a stressed regime of irrigation (restoring $50 \%$ of crop ET) of $2300 \mathrm{~m}^{3}$ but a water used of $5380 \mathrm{~m}^{3}$. The authors (Cosentino et al., 2011; Maddaluno et al., 2011; Campi et al., 2014) who studied biomass sorghum performance in open field in Southern Italy agree that an adequate irrigation volume of at least $4000 \mathrm{~m}^{3}$ can be sufficient to obtain good yields from an economic point of view.

In general, the environmental conditions under tunnel-greenhouses appeared to be beneficial to the fast growth of all the sorghum varieties compared. In particular, the higher yields at San Marzano can be explained by the lower density of sowing and the presence of a shallow water table that sorghum roots could have reached, greatly enhancing the growth of biomass notwithstanding the limited irrigation supply. The results of Eboli are explainable taking into account the limited irrigation supply and the shorter duration of crop cycle due to the tendency to a stem elongation and bending of the plants. The excessive density of sowing coupled with the $\mathrm{N}$ soil richness was the reasons of this behaviour.

As regard the levels of $\mathrm{N}$ uptake recorded in our trials (213$280 \mathrm{~kg} \mathrm{ha}^{-1}$ at Eboli, above $300 \mathrm{~kg} \mathrm{ha}^{-1}$ at San Marzano), they can be related to $\mathrm{N}$ richness in the overabundant fertilised soils under tunnels while the reduced irrigation volumes are less connectable to detected data. Lovelli et al. (2008) in trials carried out in Basilicata in 1997-1998, measured in the first year a crop $\mathrm{N}$ uptake of $190 \mathrm{~kg} \mathrm{ha}^{-1}$ in treatment not fertilised and irrigated with volumes of 50 and $100 \%$ of Etc; an $\mathrm{N}$ uptake of 236-281 $\mathrm{kg} \mathrm{ha}^{-1}$ was measured with a dose of $\mathrm{N} 120 \mathrm{~kg} \mathrm{ha}^{-1}$ combined with the same volume referred above. We reported data related only to the first year of trial, because they point out a sorghum $\mathrm{N}$ uptake closer to what has been observed by us. In both trials, the addition of large amounts of DM as sorghum residues ( 13 to $18 \mathrm{tha}^{-1}$ ) boosted their complete mineralisation by soil microbial communities stimulated by the favourable thermal and hygrometric microclimatic conditions under greenhouse.

The efficiency (i.e. the increase of SOC per unit of input) of compost or crop residues decreases with the amount added as shown in medium and long-term experiments by Pagano et al. (2008) and Heitkamp et al. (2012), respectively. Recently, experiments were carried out in fresh-cut leafy vegetables crop systems under tunnels in Sele river Valley by using olive husk compost, biowaste compost or buffalo manure as organic conditioners (Morra et al., 2013, 2015). Tests were carried out for one or two years (two-year data not yet published) without modifying the soil tillage regime. With regard to the biowaste compost, it was observed that a dose of $13 \mathrm{tha}^{-1}$ as $\mathrm{d}$. $\mathrm{m} .\left(=3.1 \mathrm{tha}^{-1}\right.$ of organic C per year) caused the same increase of $3 \mathrm{t} \mathrm{ha}^{-1}$ of SOC after two years as the highest dose of $26 \mathrm{t} \mathrm{ha}^{-1}\left(=6.2 \mathrm{t} \mathrm{ha}^{-1}\right.$ of organic $\mathrm{C}$ per year), thus highlighting the greater efficiency of the lowest dose. The reasons for this may be: i) a lower proportion of biomass which is supposed to be more recalcitrant in soil (i.e. root system or stabilised compost); ii) a finite capacity of aggregates which

Table 6. Fresh and dry aboveground biomasses produced by the three sorghum varieties in Eboli, together with the content of biomasses in organic carbon, total nitrogen and their ratio.

\begin{tabular}{lccccc} 
Variety & Fresh biomass $\left(\mathrm{t} \mathrm{ha} \mathrm{a}^{-1}\right)$ & Dry biomass $\left(\mathrm{t} \mathrm{ha} \mathrm{a}^{-1}\right)$ & Organic C $\left(\mathrm{t} \mathrm{ha} \mathrm{a}^{-1} \mathrm{DM}\right)$ & Total N $\left(\mathrm{kg} \mathrm{ha}^{-1} \mathrm{DM}\right)$ & $\mathrm{C} / \mathrm{N}$ \\
BMR 201 MH & $86.5^{\mathrm{b}}( \pm 1.6)$ & $11.6( \pm 0.47)$ & $5.0( \pm 0.24)$ & $213( \pm 38)$ & 25 \\
Goliath & $105.0^{\mathrm{a}}( \pm 6.4)$ & $13.2( \pm 1.11)$ & $5.8( \pm 0.53)$ & $216( \pm 6)$ & 27 \\
\hline BMR 333 & $102.3^{\mathrm{ab}}( \pm 2.9)$ & $14.5( \pm 0.39)$ & $6.3( \pm 0.16)$ & $283( \pm 12)$
\end{tabular}

$\mathrm{C}$, carbon; N, nitrogen; DM, dry matter; BMR, brown midrib. Standard error of means $(\mathrm{n}=3)$ are reported within brackets. a, bifferent letters in the same column separate means in agreement with Tukey's test $(\mathrm{P}<0.05)$.

Table 7. Annual balance of soil organic carbon in the 0-30 cm layer after incorporating the aboveground biomass of three sorghum varieties, Eboli.

\begin{tabular}{|c|c|c|c|c|c|c|}
\hline Eboli & 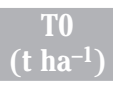 & $\begin{array}{c}\mathrm{T} 1 \\
\left(\mathrm{t} \mathrm{ha}^{-1}\right)\end{array}$ & $\begin{array}{c}\text { T1-T0 } \\
\left(\mathrm{t} \mathrm{ha}^{-1}\right)\end{array}$ & $\begin{array}{l}\text { Cover crop C input } \\
\left(\mathrm{t} \mathrm{ha}^{-1}\right)\end{array}$ & $\begin{array}{c}\text { C conversion efficiency* } \\
(\%)\end{array}$ & $\begin{array}{c}\text { SOC losses }^{\circ} \\
\left(\mathrm{t} \mathrm{ha}^{-1}\right)\end{array}$ \\
\hline Not treated & 47.7 & $43.7( \pm 3.3)$ & $-4( \pm 3.3)$ & - & - & $4.0( \pm 2.2)$ \\
\hline BMR 201 & 47.7 & $47.5( \pm 3.9)$ & $-0.2( \pm 3.9)$ & $6.3(+0.16)$ & 0 & $6.5( \pm 3.8)$ \\
\hline Goliath & 47.7 & $47.2( \pm 3.1)$ & $-0.5( \pm 3.1)$ & $5.8(+0.53)$ & 0 & $6.3( \pm 3.4)$ \\
\hline BMR 333 & 47.7 & $49.5( \pm 3.7)$ & $1.8( \pm 3.7)$ & $5.0(+0.24)$ & $36(+76)$ & $3.2(+4.0)$ \\
\hline
\end{tabular}

$\mathrm{T} 0$, weight of soil organic carbon before the start of trial; T1, amount of soil organic carbon after about 12 months from biomass incorporation; T1-T0, soil organic carbon change; C, carbon; SOC, soil organic carbon; BMR, brown midrib. *[(T1-T0)/cover crop C input $] \times 100 ;{ }^{\circ}$ cover crop C input+(T1-T0). Standard error of means (n=3) are reported within brackets. 
provide physical protection of SOC against mineralisation; iii) priming of SOC by incorporation of plant residues or composts. Shabbaz et al. (2016) supported this argument with an experiment whose objective was to test how level ( 5 and $18 \mathrm{tha}^{-1}$ as DM) and type of wheat residues (above or belowground) affected SOC stabilisation in a silty-loam textured soil after 64 days of incubation. Authors concluded that the proportion of residues physically protected within aggregates decreases and priming effects increase with increasing $C$ input leading to decreasing rate of long-term $C$ stabilization within soil organic matter by increasing residue addition. Roots of wheat only at the high addition level were incorporated into the aggregates more effectively than leaves and stalk. The literature cited enables us to read the unsatisfactory soil carbon balance after one year as follows. First, the higher level of fresh and dry biomass of sorghum at San Marzano caused a priming of SOC higher than the one observed at Eboli. Second, the different textures of the two soils could have influenced the different priming effects; soil in Eboli contained a clay amount ten-times higher than soil in San Marzano (Table 1); it is known clay plays a major role in the physical and chemical protection of organic carbon. Third, soil tillage has contributed to enhance the decay of soil organic matter as widely documented also in the context of agriculture of Mediterranean regions (Balesdent et al., 2000; Basch et al., 2012). Fourth, $\mathrm{C} / \mathrm{N}$ ratio of plant tissues, alone, does not seem an indicator sufficient to predict mineralisation and stabilisation of SOC; as a matter of fact, $\mathrm{N}$ mineralisation dynamics can be interpreted in terms of critical threshold levels of litter $\mathrm{C} / \mathrm{N}$ ratio above which $\mathrm{N}$ is temporarily immobilised within microbial biomass. Crop residues with $\mathrm{C} / \mathrm{N}$ ratio below 30 usually show a continuous $\mathrm{N}$ release. Conversely, organic matter with $\mathrm{C} / \mathrm{N}$ ratio above the threshold value of 30-35 accumulates $\mathrm{N}$, due to the growth of decomposing microbes that scavenge this element from the surrounding soil, thus impairing plant growth (Bonanomi et al., 2014). But in our case, $\mathrm{C} / \mathrm{N}$ ratio of different cultivars ranged from 20 to 25 with high amount of total $\mathrm{N}$ absorbed and this evidence is consistent with the mineralisation observed except for cv BMR 333, the only one to show a positive $\mathrm{C}$ balance in Eboli trial. In this case, to explain data, we can only suppose: i) a different below/aboveground biomass ratio with prevalence of more recalcitrant root biomass; ii) concentration of other chemical constituents of tissues (i.e., lignin, polyphenols) might play a role in influencing $\mathrm{C}$ and $\mathrm{N}$ concentrations in microbial biomass and in regulating the microbial mineralisation speed of biomass (Wang et al., 2007).

\section{Conclusions}

The sorghum green manure could be considered an interesting tool in order to tackle the decay of soil organic matter and, as a consequence, of soil quality in the intensive rotations of baby leaf crops under greenhouse. The experiments above discussed, pointed out the following: i) in 50-60 days sorghum varieties are able to produce a high fresh and dry biomass through which a high quantity of organic $\mathrm{C}$ is transferred in soil and a high quantity of total $\mathrm{N}$ is recovered from soil; ii) a seeding rate of maximum $30 \mathrm{~kg} \mathrm{ha}^{-1}$ appear sufficient to obtain the highest yield of biomass, thus reducing the costs of green manure. However, the analysis of soil $\mathrm{C}$ balance after one year from sorghum burial in soil put in evidence negative results excepted for cv BMR 333 at Eboli site. It has to be kept in mind that, as reported in Pagano et al. (2008) and Bonanomi et al. (2014), in the first year of compost organic amendment soil microbial community can increase SOC minerali- sation or reduce it depending on the level of $\mathrm{N}$ availability in soil and its chemical recalcitrance. Differently from compost, a cover crop supplies fresh biomass that can be mineralised quickly depending on the composition of its tissues. One year of observations is not enough to understand what balance-we can reach in the soil. Therefore, it is desirable that further studies are carried out in order to tune density of sowing and irrigation supply in relation to fresh and dry biomass produced as well as to assess the effect of repeated organic amendments by sorghum as cover crop.

\section{References}

Balesdent J, Chenu C, Balabane M, 2000. Relationship of soil organic matter dynamic to physical protection and tillage. Soil Tillage Res. 53:215-30.

Basch G, Carvalho M, Barros JFC, Calado JMG, 2012. Impact of soil tillage and land use on soil organic carbon decline under Mediterranean conditions. Agrociencia Uruguay 16:175-82.

Bonanomi G, D'Ascoli R, Antignani V, Capodilupo M, Cozzolino L, Marzioli R, Puopolo G, Rutigliano FA, Scelza R, Scotti R, Rao MA, Zoina A, 2011. Assessing soil quality under intensive cultivation and tree orchards in Southern Italy. Appl. Soil Ecol. 47:184-94.

Bonanomi G, D'Ascoli R, Scotti R, Gaglione SA, Gonzalez Caceres M, Sultana S, Scelza R, Rao MA, Zoina A, 2014. Soil quality recovery and crop yield enhancement by combined application of compost and wood to vegetables grown under plastic tunnels. Agr. Ecosyst. Environ. 192:1-7.

Campbell CA, McConkey BG, Gameda S, Izaurralde RC, Liang BC, Zentner RP and Sabourin D, 2002. Efficiencies of conversion of residue C to soil C. In: J.M. Kimble, R. Lal, R.F. Follett (eds.) Agricultural practices and policies for carbon sequestration in soils. Lewis Publ., Boca Raton, FL, USA, pp. 305-13.

Campi P, Navarro A, Palumbo AD, Solimando M, Lonigro A, Mastrorilli M, 2014. Productivity of energy sorghum irrigated with reclaimed wastewater. Ital. J. Agron. 9:115-9.

Colombo C, Mondelli D, 2015. Sostanza organica e carbonio organico. In: C. Colombo, T. Miano (eds.) Metodi di analisi chimica del suolo. Pubblicità \& Stampa, Modugno (BA), Italy, pp. 254-6.

Colucci M, 2012. Il sovescio con sorgo in coltura protetta: una novità per la serra. Available from: http://agronotizie.imagelinenetwork.com/fertilizzanti/2012/01/12/il-sovescio-consorgo-in-coltura-protetta-una-novitagrave-per-la-serra/14656

Cosentino SL, 1996. Crop physiology of sweet sorghum (Sorghum bicolor (L.) Moench.) in relation to water and nitrogen stress. pp. 30-41 in Proc. First European Seminar on Sorghum, Toulouse, France.

Cosentino LS, Copani V, Mantinei M, Foti S, 2002. Risposta di una coltura di sorgo a diversi livelli di energia ausiliaria. Riv. Agron. 36:357-65.

Cosentino LS, Mastrorilli M, Saita A, Scalici G, 2011. Tecnica colturale del sorgo da biomassa nel Sud Italia. In: L. Pari (ed.) Lo sviluppo delle colture energetiche in Italia. Il contributo dei progetti di ricerca SUSCACE e FAESI. CRA, Rome, pp. 51737.

Creamer NG, Baldwin KR, 2000. An evaluation of summer cover crops for use in vegetable production systems in North Carolina. HortScience 35:600-3.

EIP-AGRI Focus Group, 2015. Soil organic matter in Mediterranean regions. Available from: http://www.ec.europa. 
eu/eip/agriculture/sites/agri-eip/files/eip-agri_fg_soil_organic matter final report 2015 en $0 . p d f$

Garofalo P, Vonella AV, Ruggieri S, Rinaldi M, 2011. Water and radiation use efficiencies of irrigated biomass sorghum in a Mediterranenan environment. Ital. J. Agron. 6:133-9.

Grossman RB, Reinsch TG, 2002. Bulk density and linear extensibility. In: W.A. Dick, G.C. Topp (eds.) Methods of soil analysis. Part 4. Physical methods. SSSA, Madison, WI, USA, pp. 201-28.

Heitkamp F, Wendland M, Offenberger K, Gerold G, 2012. Implication of input estimations, residue quality and carbon saturation on the predictive power of the Rothamsted carbon model. Geoderma 170:168-75.

Italian Republic, 1999. Official methods of soil chemical analysis. In: Official Journal, n. 185, 21 October 1999. Available (in Italian) from: http://www.gazzettaufficiale.it/eli/id/1999/ 10/21/099A8497/sg

Jones RJA, Hiederer R, Rusco E, Loveland PJ, Montanarella L, 2004. The map of organic carbon in topsoils in Europe, Version 1.2, September 2003. Office for Official Publications of the European Communities, Luxembourg. Available from: https://ec.europa.eu/jrc/en/publication/eur-scientific-and-technical-research-reports/map-organic-carbon-topsoils-europe

Lazzerini G, Migliorini P, Moschini V, Pacini C, Merante P, Vazzana C, 2014. A simplified method for the assessment of carbon balance in agriculture: an application in organic and conventional micro-agroecosystems in a long term experiment in Tuscany, Italy. Ital. J. Agron. 9:55-62.

Lovelli S, Monteleone M, Posca G, Perniola M, 2008. nitrogen balance during sweet sorghum cropping cycle as affected by irrigation and fertilization rate. Ital. J. Agron. 4:253-60.

Maddaluno C, Forleo N, Garofalo P, Vonella AV, Ruggieri S, Rinaldi M, 2011. Produttività e consumi idrici di sorgo da biomassa. pp. 8-11 in Proc. 8th AISTEC Congress, Aci Castello
(CT), Italy.

Morra L, Baiano S, Di Mola I, Ottaiano L, Mori M, 2013. First results on soil Carbon and Nitrogen dynamics in a rotation with fresh-cut leafy vegetables under greenhouse after the amendment by olive husks compost. Proc. of International Conference "Biochars, Composts, and Digestates: Production, Characterization, Regulation, Marketing, Uses and Environmental Impact”, 17-20 October 2013, Bari, Italy.

Morra L, Bilotto M, Baiano S, Saviello G, Cerrato D, 2015. Annual effects of different organic fertilisers in a baby leaf crops system under tunnel in Southern Italy. Ital. J. Agron. 10:144-50.

Pagano L, Iovieno P, Zaccardelli M, Morra L, 2008. Soil organic matter dynamic as affected by municipal food waste compost fertilization in Southern Italy. In: C. Dazzi, E. Costantini (eds.) The soils of tomorrow: soils changing in a changing world. Catena Verlag Gmbh, Reiskirchen, Germany, pp. 357-70.

Penati M, Ferrante A, Martinetti L, Quattrini E, Marino P, Schiavi M, Falavigna A, Salamone F, Sari M, Frigeni S, Rocchetti R, Facchetti M, 2009. Asportazioni di elementi nutritivi ed ottimizzazione della fertilizzazione delle colture da foglia destinate alla IV gamma. Regione Lombardia - Direzione Generale Agricoltura, Milan, Italy.

Shabbaz M, Kuzyakov Y, Heitkamp F, 2016. Decrease of soil organic matter stabilization with increasing inputs: mechanisms and controls. Geoderma (in press).

Wang QR, Li YC, Klassen W, 2007. Changes of soil microbial biomass carbon and nitrogen with cover crops and irrigation in a tomato field. J. Plant Nutr. 30:623-39.

Zdruli P, Jones RJA, Montanarella L, 2004. Organic matter in the soils of Southern Europe. European Soil Data Centre, Luxembourg. Available from: http://eusoils.jrc.ec.europa.eu/ content/organic-matter-soils-southern-europe 